Revista Brasileira de Farmacognosia Brazilian Journal of Pharmacognosy 22(3): 580-586, May/Jun. 2012

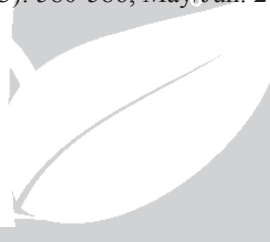

Article

Received 21 Jan 2011

Accepted 30 Aug 2011

Available online 24 Jan 2012

Keywords:

Annonaceae

Annona coriacea

araticum

hepatotoxicity

plant toxicity

ISSN 0102-695X

http://dx.doi.org/10.1590/S0102-

$695 \times 2012005000015$

\section{Investigation of the toxic potential of crude ethanol extract of Annona coriacea (araticum) seeds in acute exposed mice}

\author{
Guilherme Nobre L. do Nascimento, ${ }^{1,2}$ Marize Campos \\ Valadares, ${ }^{2}$ Hisao Nishijo, ${ }^{3}$ Tales Alexandre Aversi-Ferreira ${ }^{* 3}$
}

\author{
${ }^{1}$ Laboratórios de Bioquímica e Neurociências, Departamento de Enfermagem, \\ Universidade Federal do Tocantins, Campus of Palmas, Brazil, \\ ${ }^{2}$ Laboratório de Farmacologia Celular e Toxicologia, Universidade Federal de \\ Goiás, Brazil, \\ ${ }^{3}$ System Emotional Science, Graduate School of Medicine and Pharmaceutical \\ Sciences, University of Toyama, Japan.
}

\begin{abstract}
In this study, Annona coriacea Mart., Annonaceae, was examined for possible toxic effects on brain, liver and kidney of mice exposed to crude extract of the seeds (CESAN) of this plant. CESAN was administered by gavage for four days at doses of $12.5,25,50$, and $100 \mathrm{mg} / \mathrm{kg} /$ day. Significant changes on liver were observed, which showed reduction in the number of hepatocytes per area and increase the apoptotic index in the exposed groups, and changes in the cytoplasm and nucleus of these cells and reduced consumption of water and feed in these animals. For the other studied areas, brain and kidneys showed no changes in the parameters used in this study. The results suggest hepatotoxic effects of CESAN, but without damage to brain and kidneys in this experiment, showing a toxic potential to this species, as to the Annonaceae family.
\end{abstract}

\section{Introduction}

The Annonaceae family consists of 130 genera and 2000 species of tropical fruit (Alali et al., 1999; Almeida et al., 1998; Santos \& Salatino, 2000; Cruvinel et al., 2007) with pharmaceutical and economic potential (Braga Filho et al., 2007; Ribeiro et al., 2009). This family has plants such as cherimoya (A. cherimoia), ox-heart ( $A$. reticulata), custard-apple ( $A$. squamosa) and Brazilian pawpaw (A. muricata) (Ribeiro et. al., 2000). Concern about this family is due to the promising studies linking them to cytotoxic (Sahpaz et al., 1994; Jaramilho et al., 2000; Osorio et al., 2007); antiprotozoal (Jaramilho et al., 2000; Grandic et al., 2004; Osorio et al., 2007; Toledo et al., 2011) and it has recently been verified that the extract of Annona coriacea Mart., Annonaceae, obtained from Brazilian cachaça presents activity against the promastigote form of Leishmania amazonensis at concentration $175 \mu \mathrm{L} / \mathrm{mL}$ (Toledo et al., 2011); and antitumoral effects (Rupprecht et al., 1990; Ahammadsahib et al., 1993; Alali et al., 1999), as well as inhibitory activity on cell growth (Cavé et al., 1997; Tormo et al., 1999), what makes plants such as $A$. muricata and $A$. cherimoya, future candidates for drugs (Oberlies et al., 1997; Tormo et al., 1999; Liu et al., 2007), as well as Annona coriacea.
Inhibitory activity on the complex-I (NADH: ubiquinone oxidoreductase) of mitochondrial respiratory chain in mammals and insects has been related to this family, whose activity was attributed to acetogenins, the most important class of substances found in this family (Londerhausen et al., 1991; Degli Esposti et al., 1994; Hollingworth et al., 1994; Degli Esposti, 1998; Tormo et al., 1999; Lannuzel et al., 2003).

Annona coriacea Mart., Annonaceae, is a native fruit of Brazil disseminated across the Cerrado region. Its popular name, araticum, is given to different species from the same family, being known by other names as popular marola, articum and araticum-liso (Ruprecht et al., 1990; Almeida et al., 1998; Fagundes et al., 2005; Coelho et al., 2006). The araticum fruit is consumed by the population for the treatment of inflammatory processes, to a lesser extent, as food (Fagundes et al., 2005) and as digestive (Agra et al., 2008). However, studies on this species have not corroborated its popular use (Champy et al., 2004).

According to Coelho et al. (2003 and 2006) A. coriacea generates hemagglutinating activity on human erythrocytes, and induction of neutrophil migration into the peritoneal cavity of mice resulting in inflammatory response; its activities are related to lecithin isolated from the seeds of this plant. Two acetogenins, coriadienin and gigantetronenin, were isolated from roots; both 
have cytotoxic activity (Silva et al., 1996). According to Fagundes et al. (2005) the CESAN generates an increase of micronuclei in cells from bone marrow and genotoxic activity in mice.

Given the popular use of $A$. coriacea as food or for medicinal purposes and in view of the large number of studies linking toxic activities of the Annonaceae family, this study aimed to investigate possible toxic activities of this plant on brain, liver and kidney.

\section{Material and Methods}

\section{Plant material}

Annona coriacea Mart., Annonaceae, was collected between March and October 2001 in Senador Canedo, Goiás, Brazil. The material was identified by Dr. José Ângelo Rizzo, curator of the Federal University of Goiás Herbarium collections, and a voucher specimen was deposited (reference number 40004) in the herbarium of that university.

\section{Preparation of plant extract}

Pulverized dried $A$. coriace seeds (100 g) were exhaustively macerated with $500 \mathrm{~mL}$ ethanol $(70 \% \mathrm{v} / \mathrm{v})$ for $5 \mathrm{~h}$ with mechanic agitation for three times. The plant ethanol extracts were then concentrated in a rotating evaporator under reduced pressure at $40{ }^{\circ} \mathrm{C}$ until all solvent was evaporated, which resulted in CESAN.

\section{Animals}

Male Swiss mice (25-30 g), from the "Indústria Química de Goiás" (IQUEGO) were used. The animals were separated and housed (five per cage) in standard plastic cages with stainless steel coverlids and wood shavings as bedding. Photoperiod (12 L:12 D), room temperature $\left(23 \pm 1{ }^{\circ} \mathrm{C}\right)$ were controlled in the animal facilities. All mice had free access to water and were fed ad libitum with a commercial rodent diet. The amount of food and water consumption, excreta and weight were evaluated during the experiment. Experiments were approved by Ethics Committee from Federal University of Goiás protocol number 162/06 [CEPMHA/HC/UFG] and conducted in accordance with the "Colégio Brasileiro de Experimentação Animal" (COBEA) and Food and Drugs Administration (FDA).

\section{Treatment}

Mice were divided into six groups (five mice/ group). CESAN was dissolved in tween-80 and saline [1:10] and given as a single dose per day for four days orally by oral feeding tubes as follows: Group I: Control (saline), Group II: Vehicle control (tween 80 and saline [1:10]/mouse/day), Group III: A. coriacea extract (12.5 $\mathrm{mg} / \mathrm{kg}$ body weight/day), Group IV: $A$. coriacea extract ( $25 \mathrm{mg} / \mathrm{kg}$ body weight/day), Group V: $A$. coriacea extract (50 mg/kg body weight/day), Group VI: A. coriacea extract (100 mg/kg body weight/day).

The proceedings were realized according to Olfert et al. (1993) and Fagundes et al. (2005).

\section{Histology}

From all groups, liver, kidney and encephalon samples were collected $24 \mathrm{~h}$ after the last administration of CESAN. Histological preparations were carried out with treated and control samples, which were fixed in ethanol $(70 \%)$ for two weeks. In the post fixation, the tissues were dehydrated in a graded ethanol series, xylol and embedded in paraffin. Thin sections $(6 \mu \mathrm{m})$ were stained with hematoxylin and eosin (HE) (Fagundes et al., 2005).

\section{Morphometric analysis}

The images were captured using a light microscope Leica DMI 4000B coupled to a Leica camera and computer, and a light microscope Leica DM 2000 coupled to a Canon PowerShot S80 camera. The morphometric analysis was performed using the ImageJ 1.40 software and Leica Application Suite.

In the cortex of frontal, parietal and occipital lobes, midbrain and olfactory bulb, images with $40 \mathrm{x}$ objective with total area of $38000 \mu \mathrm{m}^{2}$ were made, and the number of cells per area was analyzed. For the cerebellum, the images were made with 20x objective, with total area of $152550 \mu \mathrm{m}^{2}$, as well as the number of cells per area in the molecular layer and Purkinje cells layer (Souza et al., 2006; Moreno et al., 2007).

The analysis of the liver was performed at 1008x magnification with total area of $19000 \mu \mathrm{m}^{2}$, with cell frequency/area calculation (Moreno et al., 2007).

For the kidneys, internal diameter (limit of the glomerulus), external diameter (distance between the boundaries of Bowman's capsule) and area of Bowman's capsule were calculated (Moreno et al., 2007). Images were obtained with 640x magnification with total area of $47.200 \mu \mathrm{m}^{2}$.

\section{Apoptotic index}

Apoptosis was quantified by morphometry using digitized images of liver slides stained with HE. The minimum number of representative microscopic fields per sample was determined from the count of a blade 40x magnification in fifteen fields. The captured fields were grouped in three sub-samples with increasing number of fields $(5,10$ and 15) at random and with replacement. 
For each sub-group, the arithmetic mean and standard deviation were calculated. Once the increase in the number of fields did not result in significant reduction in the standard deviation, the minimum number of representative fields was considered (Moro et al., 2004; Fagundes et al., 2005). In this study, this number occurred after counting ten fields.

Apoptotic cells were identified as showing at least two of the following characteristics: shrunken anoykic, nuclear condensation, nuclear fragmentation, formation of apoptotic bodies and dense nuclear staining compared to normal cells due to chromatin condensation. follows:

The apoptotic index (AI) was then calculated as

$$
A I=\frac{\sum \text { apoptotic cells }}{\sum \text { total cells }} \times 100
$$

\section{Statistical analyses}

Statistical comparisons were made using the GraphPad Prism 5 software. The results were presented as mean \pm standard deviation. Normal parametric variables were compared between groups using ANOVA and subsequent Tukey test. $p$-values $<0.001$ were considered significant.

\section{Results}

Data for the consumption of food, water and excreta (Table 1) showed reduction in groups exposed to CESAN compared to control groups. Moreover, changes in the body weight between groups did not differ significantly (Table 2).

In different brain areas studied here, frontal, parietal and occipital lobe, cerebellum, midbrain and olfactory bulb (Figure 1), no evidence of significant morphological change was found according to methods used in this study. The same occurred with kidneys (Figure 2A, B, C), where different parameters such as internal and external diameter and area of Bowman's capsule were used.

For the liver, changes in cell frequency/area were evident (Figure 2D). The groups exposed to CESAN presented significant differences when compared to control groups $(p<0.001)$, and a significant difference was also observed when comparing the group of 25,50 and $100 \mathrm{mg} /$ $\mathrm{kg}$ body weight/day group and the lowest dose $(12.5 \mathrm{mg} /$ $\mathrm{kg}$ /day). The morphology of liver cells shows the presence of shrinkage and changes in the nucleus and cytoplasm condensation (Figure 3).

The light microscopy revealed an increase in the number of apoptotic cells (Table 2) with increasing dose of CESAN administered when compared to control groups.

Table 1. Effect of CESAN on the average food $(\mathrm{g})$ and water $(\mathrm{mL})$ consumption and excreta $(\mathrm{g})$ per experimental group ( $\mathrm{n}=5)$ per day of treatment.

\begin{tabular}{|c|c|c|c|c|c|c|c|c|c|c|c|c|}
\hline \multirow{2}{*}{ Group } & \multicolumn{3}{|c|}{ Day 1} & \multicolumn{3}{|c|}{ Day 2} & \multicolumn{3}{|c|}{ Day 3} & \multicolumn{3}{|c|}{ Day 4} \\
\hline & Food & Water & Excreta & Food & Water & Excreta & Food & Water & Excreta & Food & Water & Excreta \\
\hline 1 & 26.65 & 40 & 23,81 & 32.46 & 44 & 22,79 & 27.97 & 40 & 19,4 & 29.72 & 48 & 22,8 \\
\hline 2 & 32.72 & 44 & 21,1 & 32.74 & 40 & 18,49 & 29.1 & 36 & 18,01 & 33.8 & 44 & 17,7 \\
\hline 3 & $12.48^{*}$ & $20 *$ & $14,52 *$ & $21.94 *$ & $22 *$ & $13,65^{*}$ & $20^{*}$ & $28 *$ & $13,13^{*}$ & $16.1 *$ & $26^{*}$ & $9,34^{*}$ \\
\hline 4 & $13.42 *$ & $18^{*}$ & $13,8^{*}$ & $19.79 *$ & $27,5^{*}$ & $12,05 *$ & $19.36^{*}$ & $25^{*}$ & $8,7^{*}$ & $20.13^{*}$ & $35^{*}$ & $10,88^{*}$ \\
\hline 5 & $11.15^{*}$ & $25^{*}$ & $11,95^{*}$ & $12.55^{*}$ & $26,67 *$ & $3,97 *$ & $15.67 *$ & $23,34^{*}$ & $6,77^{*}$ & $16.83^{*}$ & $26,67^{*}$ & $5,33 *$ \\
\hline 6 & $10.46^{*}$ & $18^{*}$ & 7.9* & $16.52 *$ & $28^{*}$ & $13,8^{*}$ & $17.44^{*}$ & $27,5^{*}$ & $10,16^{*}$ & $12 *$ & $22,5^{*}$ & $2,8^{*}$ \\
\hline
\end{tabular}

1. control group; 2. vehicle control (tween+saline); 3. Annona coriacea extract $12.5 \mathrm{mg} / \mathrm{kg}$ body weight/day; 4 . Annona coriacea extract $25 \mathrm{mg} / \mathrm{kg}$ body weight/day; 5. Annona coriacea extract $50 \mathrm{mg} / \mathrm{kg}$ body weight/day; 6 . Annona coriacea extract $100 \mathrm{mg} / \mathrm{kg}$ body weight/day. *Significantly different from group control and vehicle control $p<0.001$.

Table 2. Effect of CESAN on the body weight ( $\mathrm{g}$ ) and apoptotic index (\%) per experimental group ( $\mathrm{n}=5)$ per day of treatment.

\begin{tabular}{|c|c|c|c|c|c|}
\hline \multirow{2}{*}{ Group } & \multicolumn{4}{|c|}{ Weight $(g) \pm$ S.D. } & \multirow{2}{*}{$\begin{array}{l}\text { Apoptotic Index } \\
\text { Average }(\%) \pm \text { S.D. }\end{array}$} \\
\hline & Day 1 & Day 2 & Day 3 & Day 4 & \\
\hline 1 & $35,38 \pm 2,58$ & $35,60 \pm 2,98$ & $36,11 \pm 3,13$ & $36,70 \pm 3,65$ & $12,08 \pm 2,55$ \\
\hline 2 & $37,62 \pm 3,08$ & $38,33 \pm 3,04$ & $38,44 \pm 3,53$ & $37,88 \pm 2,22$ & $13,83 \pm 2,86$ \\
\hline 3 & $31,08 \pm 5,27$ & $29,65 \pm 4,21$ & $30,32 \pm 4,12$ & $30,52 \pm 4,10$ & $27,66 \pm 2,65^{*}$ \\
\hline 4 & $34,36 \pm 7,70$ & $33,34 \pm 7,16$ & $36,83 \pm 3,42$ & $36,00 \pm 1,87$ & $48,97 \pm 2,81 * \mathrm{o}$ \\
\hline 5 & $33,06 \pm 1,59$ & $33,01 \pm 2,68$ & $33,20 \pm 2,52$ & $33,10 \pm 3,17$ & $58,17 \pm 5,49^{* \circ \Delta}$ \\
\hline 6 & $30,16 \pm 6,43$ & $28,84 \pm 6,57$ & $32,71 \pm 3,06$ & $31,86 \pm 3,05$ & $60,47 \pm 4,25^{* \circ \Delta}$ \\
\hline
\end{tabular}

1. control group; 2. vehicle control (tween+saline); 3. Annona coriacea extract $12.5 \mathrm{mg} / \mathrm{kg}$ body weight/day; 4 . Annona coriacea extract $25 \mathrm{mg} / \mathrm{kg}$ body weight/day; 5 . Annona coriacea extract $50 \mathrm{mg} / \mathrm{kg}$ body weight/day; 6 . Annona coriacea extract $100 \mathrm{mg} / \mathrm{kg}$ body weight/day. Data represent the average $\pm \mathrm{SD} ; \mathrm{n}=5$. * Significant difference compared to group control and vehicle control for $p<0.001 ;{ }^{\circ}$ Significant difference compared to experimental group $3 ;{ }^{\Delta}$ Significant difference compared to the experimental group 4. 

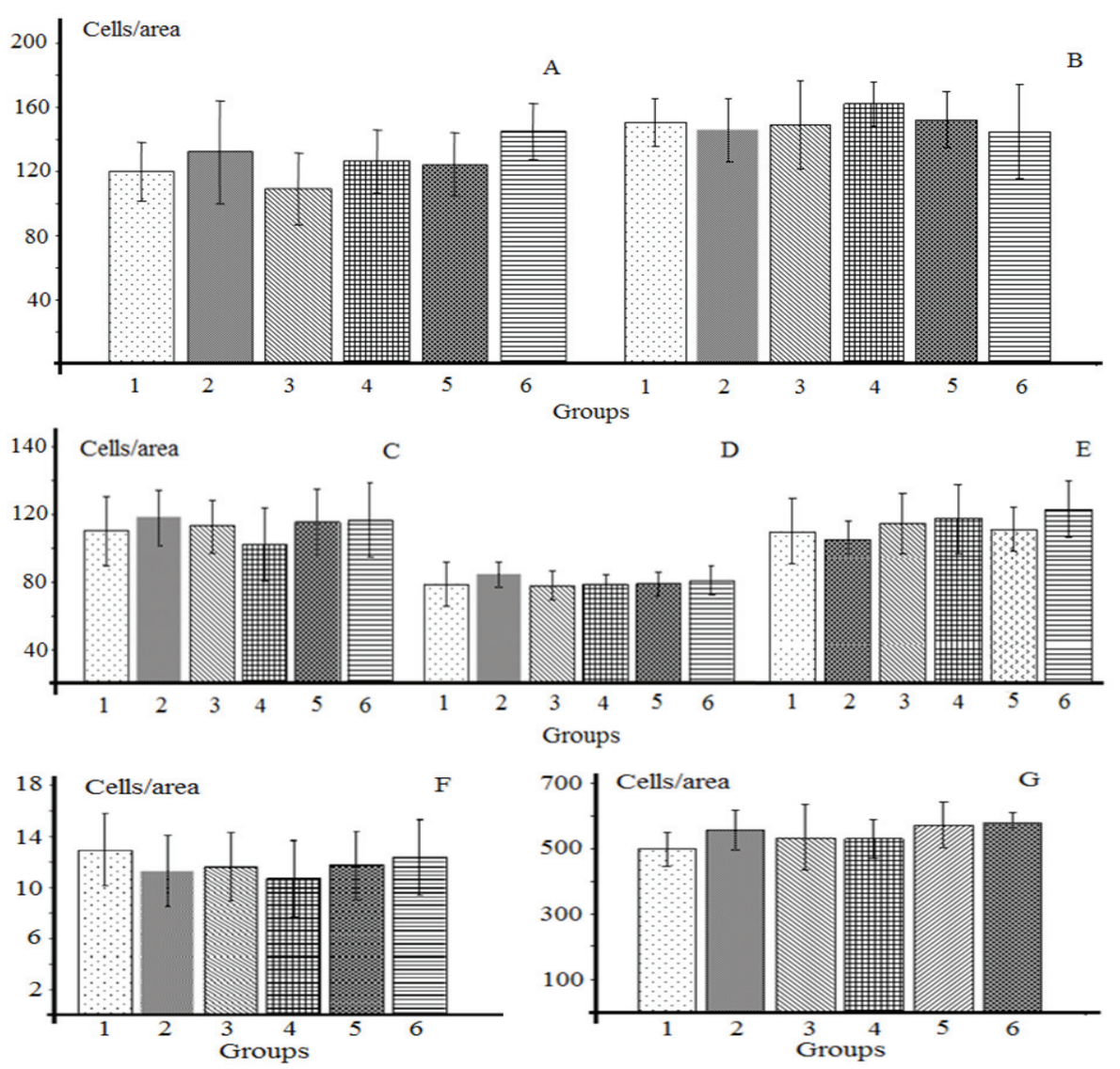

Figure 1. Frequency of cells per area of the parietal (A) and occipital lobe (B), molecular layer of cerebellum (C), frontal lobe (D), midbrain (E), Purkinje's cells of the cerebellum (F) and olfactory bulb (G). Columns are the average \pm SD of twenty slides per group 1. control group; 2. vehicle control (tween+saline); 3. Annona coriacea extract $12.5 \mathrm{mg} / \mathrm{kg}$ body weight/day; 4 . Annona coriacea extract $25 \mathrm{mg} / \mathrm{kg}$ body weight/day; 5. Annona coriacea extract $50 \mathrm{mg} / \mathrm{kg}$ body weight/day; 6. Annona coriacea extract $100 \mathrm{mg} / \mathrm{kg}$ body weight/day).
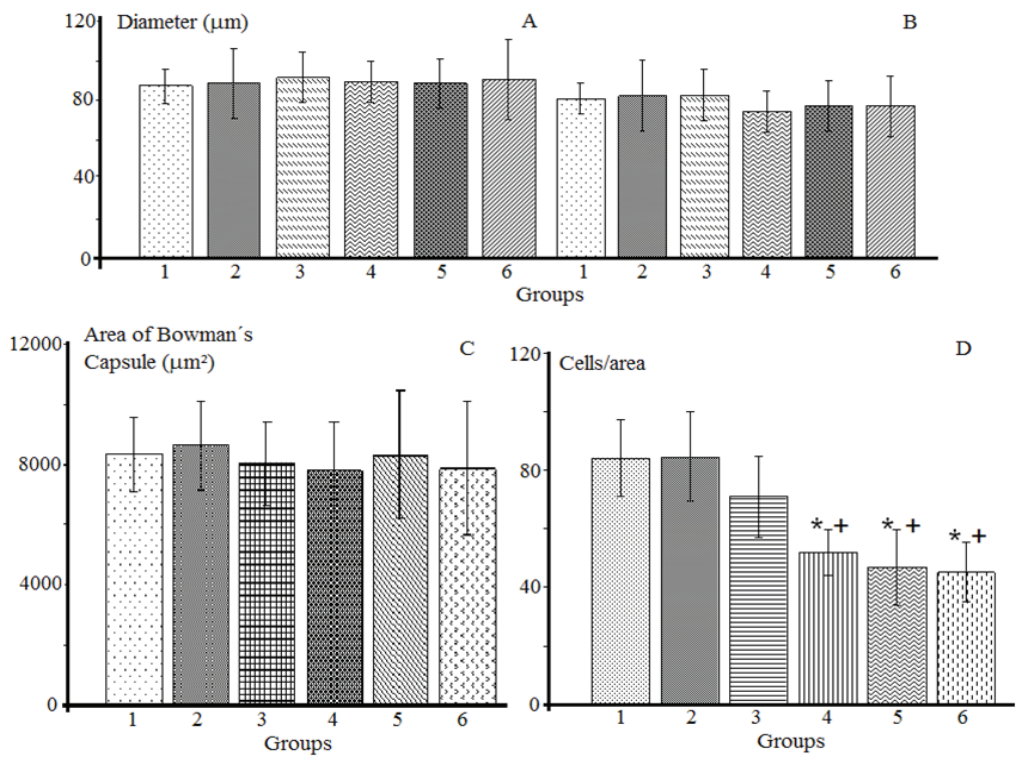

Figure 2. Results of external diameter (A) and internal diameter (B), area of Bowman's capsule (C) and frequency of cells per area of liver (D). Columns are the average $\pm \mathrm{SD}$ of twenty slides per group; 1. control group; 2. vehicle control (tween + saline); 3. Annona coriacea extract $12.5 \mathrm{mg} / \mathrm{kg}$ body weight/day; 4 . Annona coriacea extract $25 \mathrm{mg} / \mathrm{kg}$ body weight/day; 5 . Annona coriacea extract 50 $\mathrm{mg} / \mathrm{kg}$ body weight/day; 6. Annona coriacea extract $100 \mathrm{mg} / \mathrm{kg}$ body weight/day). *Significant difference compared to group control and vehicle control for $p<0.001$. ${ }^{+}$Significant difference compared to the experimental group; A. coriace extract $12.5 \mathrm{mg} / \mathrm{kg}$ body weight/day for $p<0.001$. 

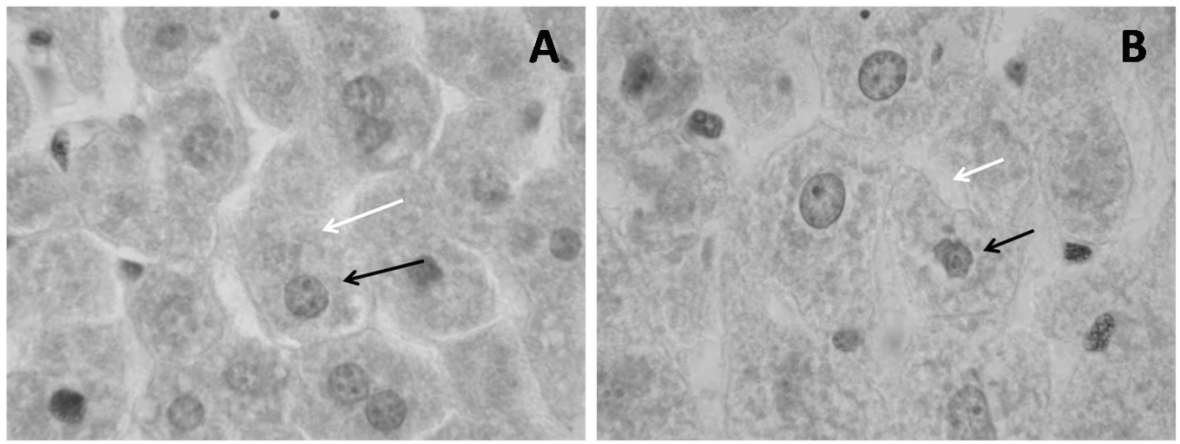

Figure 3. Morphological differences of the cell nucleus (black arrows) and cytoplasm (white arrows) of hepatocytes of control groups (A) and exposed to higher dose used in this study (100 mg/kg body weight/day) (B), respectively (increase in $1000 \mathrm{x}$ HE).

\section{Discussion}

Data on food and water consumption, and weight of excreta show that alcoholic CESAN has toxic effects on the treated animals. Group II that received Tween 80 and saline had no change in relation to group I who received only saline, but treated groups III to VI showed significant differences at $p<0.001$ for both $\mathrm{F}$ and Tukey tests, for food and excreta variations in relation to groups I and II.

Annonaceae have acetogenins that are inhibitors of complex I respiratory chain (NADH ubiquinone reductase) (Degli Esposti, 1998; Tormo et al., 1999). These substances decrease the general metabolism of the organism and may cause a decrease in feeding activity of animals, at least in the four days of the experiment, enough time to cause decreased body weight of animals in terms of statistical significance, data that putatively can be explained by the small amount of use of body reserves within this time period.

The absence of perceptual morphological alterations in the amount of brain cells in quantitative terms can also be explained by the acute study, since according to Champy and colleagues (2004), the inhibitory activity of the respiratory chain induces neurodegeneration in mice, with reduction of $44 \%$ in ATP production in the cerebral cortex, causing cell loss in the basal ganglia.

For the midbrain, toxic activity and cell death have been reported in cultured dopaminergic neurons in the midbrain of rats exposed to acetogenins (Lannuzel et al., 2003). In this study, the fact that no changes occur in mesencephalic cells may be associated with the effects of CESAN and not of acetogenins in particular.

The activities of acetogenins are in agreement with reports from Caparros-Lefebvre $(1999,2002)$ and Lannuzel et al. (2007), correlating the appearance, in a Caribbean population that used tea and fruits of plants from the Annonaceae family, of a atypical Parkinsonian syndrome caused by atrophy in regions of the cerebral cortex, midbrain, cerebellum and corpus callosum.

Hypothetically, in quantitative and temporal terms, the blood brain barrier may have been sufficient to protect the brain from the toxic effects observed by other authors, and this barrier was absent in the cell culture study. The blood-brain barrier hypothesis may explain the absence of changes in the olfactory bulb, a region where there is constant generation of new neurons (Bedard \& Parent, 2004), as occurs in the liver, because this result, in particular, is indicative of the previously mentioned effect due to the action of CESAN observed in post-mitotic cells, such as changes in the apoptotic index observed in the liver of animals treated in this study.

Therefore, an amount-time-toxic effect relationship needs to be checked for the action of extracts from the Annonaceae family, which have proven to have cytotoxic and antitumoral activity (Oberlies et al., 1997; Jaramilho et al., 2000; Grandic et al., 2004; Osorio et al., 2007), and in particular, extracts derived from Annona coriacea Mart., Annonaceae, showing inflammatory action, recruitment of neutrophils to the peritoneal cavity of mice and hemagglutinating activity on human and animal erythrocytes (Coelho et al., 2003, 2006).

In the liver, the decrease in the number of cells per area, changes in the morphology of nucleus of hepatocytes and cytoplasm vacuolization (Figure 3), in addition to reduced water and food consumption and excreta production, suggest hepatotoxicity.

Liver alterations may explain the absence of morphological alterations in the brain and kidneys, since they show the high antitoxic activity of this organ, which can decrease the concentration of active substances in circulation, reducing the potentially pathological effects of the kidney and the amount of active substances in circulation sufficient to cross the blood brain barrier.

An important fact about the liver tissue is the decrease in the number of hepatocytes, since this is an organ with great regeneration capacity due to the high 
cell mitotic activity (Greene et al., 2003; Petroianu et al., 2004).

These facts allow corroborating the toxic action of CESAN, also on cell replication, because Fagundes and colleagues (2005) reported genotoxic activity of this extract in mice after verifying the presence of micronuclei in bone marrow cells in a single dose, and data obtained in this study are in agreement with the apoptotic index obtained by the liver analysis.

Another hypothesis to be considered on the absence of morphological alterations in the brain and kidney is about the amount of potentially toxic substances of the seed such as acetogenins with higher concentration in fruits.

In conclusion, the observed changes in the feeding behavior of animals, the number of liver cells, the cell morphology of hepatocytes and the apoptotic index indicate a toxic effect of CESAN at acute treatment doses. The absence of morphological and cell number variations in kidney and brain may hypothetically be explained by (1) the antitoxic action of the liver and/or (2) the action of the blood-brain barrier (3) acute exposure, (4) low concentration of potentially toxic substances in the seeds of the plant.

\section{Acknowlegments}

We thank anonymous referees whose comments were essential to improve the final version of this manuscript.

\section{References}

Agra MF, Silva KN, Basilio JLD, Freitas PF, Barbosa-Filho JM 2008. Survey of medicinal plants used in the region Northeast of Brazil. Rev Bras Farmacogn 18: 472-508.

Ahammadsahib KI, Hollingworth RM, McGovern JP, Hui YH, McLaughlin JL 1993. Mode of action of bullatacin: A potent antitumor and pesticidal Annonaceous acetogenina. Life Sci 53: 1113-1120.

Alali FQ, Liu XX, McLaughli JL 1999. Annonaceous acetogenins: recent progress. J Nat Prod 62: 504-540.

Almeida SP, Proença CEB, Ribeiro JF 1998. Cerrado: espécies vegetais úteis. Distrito Federal: Editora da Embrapa.

Bérdard A, Parent A 2004. Evidence of newly generated neurons in the human olfactory bulb. Brain Res Rev 151: 159168.

Braga Filho JR, Veloso VRS, Naves RV, Nascimento JL, Chaves LJ 2007. Danos causados por insetos em frutos e sementes de araticum (Annona crassiflora Mart., 1841) no Cerrado de Goiás. Biosci J 23: 21-28.

Caparros-Lefebvre D, Elbaz A 1999. Possible relation of atypical parkinsonism in the French West Indies with consumption of tropical plants: a case-control study. Carribean Parkinsonism Study Group. Lancet 354:
281-286.

Caparros-Lefebvre D, Sergeant N, Lees A, Camuzat A, Daniel S, Lannuzel A, Brice A, Tolosa E, Delacourte A, Duyckaerts C 2002. Guadeloupe parkinsonism: a cluster of progressive supranuclear palsy-like tauopathy. Brain 125: 801-811.

Cavé A, Cortes D, Figadère A, Laurens A, Pettit GR 1997. Acetogenins from Annonaceae. In: Herz W, Kirby GW, Moore RE, Steglich W, Tamm C Progress in the Chemistry of Organic Natural Products Wien: 85.

Champy P, Höglinger GU, Féger J, Gleye C, Hocquemiller R, Laurens A, Guérineau V, Laprévote $\mathrm{O}$, Medja F, Lombès A, Michel PP, Lannuzel A, Hirsch EC, Ruberg M 2004. Annonacin, a lipophilic inhibitor of mitochondrial complex I, induces nigral and striatal neurodegeneration in rats: possible relevance for atypical parkinsonism in Guadeloupe. J Neurochem 88: 63-69.

Coelho MB, Souza IA, Freire MGM, Marangoni S, Antunes E, Macedo MLR 2006. Neutrophil migration in mice induced by a mannose-binding lectin isolated from Annona coriacea seeds. Toxicon 48: 529-535.

Coelho MB, Freire MGM, Toyama MH, Marangoni S, Novello JC, Macedo MLR 2003. Purification and characterization of a lectin from Annona coriacea seeds. Protein Peptide Lett 10: 165-173.

Cruvinel SRC, Rodrigues WA, Rizzo JA 2006. Flora dos estados de Goiás e Tocantis: Annonaceae - Coleção Rizzo. Brasil: 60.

Degli Esposti, M 1998. Inhibitors of NADH-ubiquinone reductase: na overview. Biochim Biophys Acta 1364: 222-235.

Degli Esposti M, Ghelli A, Ratta M, Cortes D, Estornell E 1994. Natural substances (acetogenins) from the family Annonaceae are powerful inhibitors of mitochondrial NADH dehydrogenase. Biochem J 301: 161-167.

Fagundes FA, Oliveira LB, Cunha LC, Valadares MC 2005. Annona coriacea induz efeito genotóxico em camundongos. Rev Eletr Farm 2: 24-29.

Grandic SRL, Fourneau C, Laurens A, Bories C, Hocquemiller $\mathrm{R}$, Loiseau PM 2004. In vitro antileishmanial activity of acetogenins from Annonaceae. Biomed Pharmacother 58: 388-392.

Greene AK, Wiener S, Puder M, Yoshida A, Shi B, Perez-Atayde AR, Efstathiou JA, Holmgren L, Adamis AP, Rupnick M, Folkman J, O'Reilly MS 2003. Endothelial directed hepatic regeneration after partial hepatectomy. Ann Surg 237: 530-535.

Hollingworth RM, Ahammadsahib KI, Gadelhak G, McLaughlin JL 1994. New inhibitors of complex I of the mitochondrial electron transport chain with activity as pesticides. Biochem Soc T 22: 230-233.

Jaramillo MC, Arango GJ, González MC, Robledo SM, Velex ID 2000. Cytotoxicity and antileishmanial activity of Annona muricata pericarp. Fitoterapia 71: 183-186.

Lannuzel A, Hoglinger GU, Verhaeghe S, Gire L, Belson S, 
Escobar-Khondiker M, Poullain P, Oertel WH, Hirsch EC, Dubois B, Ruberg M 2007. Atypical parkinsonism in Guadeloupe: a common risk factor for two closely related phenotypes? Brain 130: 816-827.

Lannuzel A, Michel PP, Hoglinger GU, Champy P, Jousset A, Medja F, Lombès A, Darios F, Gleye C, Laurens A, Hocquemiller R, Hirsch EC, Ruberg M 2003. The mitochondrial complex I inhibitor annonacin is toxic to mesencephalic dopaminergic neurons by impairment of energy metabolism. Neuroscience 121: 287-296.

Liu Hai-Xia, Huang GR, Zhang HM, Wu JR, Yao ZJ 2007. Annonaceous acetogenin mimics bearing a terminal lactam and their cytotoxicity against cancer cells. Bioorg Med Chem Lett 17: 3426-3440.

Londerhausen M, Leicht W, Lieb F, Moeschler H, Weiss H 1991. Molecular mode of action of annonins. Pestic Sci 33: 427-438.

Moreno SRF, Carvalho JJ, Nascimento AL, Pereira M, Rocha EK, Olej B, Caldas LQA, Bernardo-Filho M 2007. Experimental model to assess possible medicinal herb interaction with a radiobiocomplex: Qualitative and quantitative analysis of kidney, liver and duodenum isolated from treated rats. Food Chem Toxicol 45: 19-23

Moro L, Vasconcelos AC, Santos FGA, Alves CM, Nunes JES, Sampaio IBM 2004. Determination of the minimal representative number of microscopic fields to quantify apoptosis in canine lymph nodes. Arq Bras Med Vet Zoo 56: 408-410.

Oberlies NH, Croy VL, Harrison ML, McLaughlin JL 1997. The Annonaceous acetogenin bullatacin is cytotoxic against multidrug-resistant human mammary adenocarcinoma cells. Cancer Lett 115: 73-79.

Olfert ED, Cross BM, Mcwilliam AA 1993. In: Guide to the care and use of experimental animals . Canadian Council on Animal Care, Ottawa, 1, 1-11.

Osorio E, Arango GJ, Jiménez N, Alzate F, Ruiz G, Gutiérrez D, Paco MA, GimenezA, Robledo S 2007. Antiprotozoal and cytotoxic activities in vitro of Colombian Annonaceae. $J$ Ethnopharmacol 111: 630-635.

Petroianu A, Esquerdo CRM, Barbosa AJA, Alberti LR 2004. Regeneração hepática induzida por ressecção segmentar do fígado, em ratos. Rev Col Bras Cir 31: 10-14.

Ribeiro JF, Brito MA, Scaloppi Junior EJ, Fonseca CEL 2000. Araticum. Jaboticabal: FUNEP 12: 52.

Ribeiro MNO, Pasqual M, Villa F, Pio LAS, Hilhorst HWM 2009. In vitro seed germination and seedling development of Annona crassiflora Mart. Sci Agric 66: 410-413.

Ruprecht JK, Hui YH, McLaughlin JL 1990. Annonaceous acetogenins: a review. J Nat Prod 53: 237-278.

Sahpaz S, Bories C, Loiseau PM, Cortes D, Hocquemiller R, Laurens A, Cavé A 1994. Cytotoxic and antiparasitic activity from Annona senegalensis seeds. Planta Med 60: 538-540.

Santos DYAC, Salatino MLF 2000. Foliar flavonoids of Annonaceae from Brazil: taxonomic significance. Phytochemistry 55: 567-573.

Silva ELM, Roblot F, Mahuteau J, Cave A 1996. Coriadienin, the first annonaceous acetogenin with two double bonds isolated from Annona coriaceae. J Nat Prod 59: 528530.

Souza AG, Rodrigues HG, Serpa-Vieira CM, Mateus MVC, Aversi-Ferreira TA 2006. Imunohistochemical study of the cerebellum in Wistar rats submitted to acute prenatal exposure to ethanol at the $12^{\text {th }}$ day of intrauterine life. Rev Eletr Farm 3: 6-14.

Toledo CEM, Britta EA, Ceole LF, Silva ER, Mello JCP, Dias Filho BP, Nakamura CV, Ueda-Nakamura T 2011. Antimicrobial and toxicity activities of medicinal plants of the Brazilian cerrado, using Brazilian cachaça as extractor liquid. J Ethnopharmacol 133: 420-425.

Tormo JR, Gallardo T, Aragon R, Cortes D, Estornell E 1999. Specific interactions of monotetrahydrofuranic annonaceous acetogenins as inhibitors of mitochondrial complex I. Chem Biol Interact 122: 171-183.

\section{*Correspondence}

Tales Alexandre Aversi-Ferreira

System Emotional Science, Graduate School of Medicine and Pharmaceutical Sciences, University of Toyama, Sugitani 2630,

Toyama 930-0194, Japan

tales@med.u-toyama.ac.jp

Tel: +81 $764347215 ; 764345012$ 